\title{
Chemical Eye Injuries: Presentation and Management Difficulties
}

\author{
${ }^{1}$ F. G. Adepoju, ${ }^{2}$ A. Adeboye and ${ }^{3}$ I. A. Adigun \\ ${ }^{1}$ Department of Ophthalmology, College of Medicine, University of Ilorin, ${ }^{2}$ Department of Ophthalmology \\ University of Ilorin Teaching Hospital, Ilorin and ${ }^{3}$ Division of Plastic and Reconstructive Surgery, Department \\ of Surgery, College of Medicine, University of Ilorin, Ilorin, Nigeria \\ Reprint requests to: Dr. F. G. Adepoju, Department of Ophthalmology, College of Medicine, University of \\ Ilorin, Nigeria.E-mail: feyiyemiade@yahoo.com
}

\begin{abstract}
Background/Purpose: To review the pattern of presentation and management difficulty of patients with ocular chemical burns.

Method: Retrospective study of all patients with ocular burns seen over 8-year period (March 1998April 2006) in the eye clinic as well as the plastic and reconstructive surgery unit of our hospital. Case files were retrieved and relevant information extracted and analyzed.

Results: There were a total of 23 patients ( $\mathrm{n}=33$ eyes) seen in the period under review consisting of 19 males and 4 females. The age ranged from 6-52 years with mean age of 31.87years. The chemical injuries were accidental in $73.9 \%$ of the cases and of these $76.5 \%$ were work related. The remaining $26.1 \%$ resulting from assault were bilateral and led to blindness in all the patients. Main injurious agents were acid and alkali.

Conclusion: Major cause of chemical injury was work related; although blindness and disability occurred more in the cases of assault. Occupational health issues need a revisit, preparedness of health institutions to take adequate care of people with ocular burns is presently poor.
\end{abstract}

Key words: Eye, chemical injury, presentation, management difficulty

\begin{abstract}
Résumé
Introduction/Objectif : Faire le bilan de la tendance de la présentation et la prise en charge difficile des patients atteints de la brûlure chimique oculaire.

Méthode : Etude rétrospective de tous les patients avec la brûlure oculaire vus au cours d'une durée de 8 ans (mars 1998 - avril 2006) dans le centre ophtalmologique, de même que du centre chirurgical réparatice et esthétique dans notre hôpital. Dossiers médicaux ont été rétrouvés et des informations pertinentes ont été notées et analysées.

Résultats : Dans l'ensemble, il y a un nombre total de 23 patients $(\mathrm{n}=33$ yeux) vus pendant la période en cours de révision constituent 19 patients du sexe masculin et 4 du sexe féminin. La tranche d'âge de 6 - 52 ans avec l'âge moyen de 31,87 ans. Des blessures cliniques étaient accidentelles chez 73,9\% des cas dont $76,5 \%$ étaient liées au travail. Les autres patients $26,1 \%$ à la suite des coups et blessures étaient bilatéraux et ont provoqué la cécité chez tous les patients. Agents principaux des blessures étaient acide et alcali.

Conclusion: La cause principale de la blessure chimique est liée au travail, quoique la cécité et l'infirmité arrivent toujours dans les cas des blessures. Des problèmes ayant rapport è la santé professionnelle éxige une nouvelle perspective. Actuellement, l'état de préparation des centres hospitaliers de soigner bien convenablement les gens atteints des brûlures oculaires est mauvais.
\end{abstract}

Mot-clés : Oeil, blessure chimique, présentation, problème de la prise en charge

\section{Introduction}

Chemical injury to the eye is an ophthalmic emergency due to the potential for visual loss which is often related to the severity of initial insult as well as the initial first aid treatment. ${ }^{1,2}$ Chemical injury forms a small but significant part of ocular trauma. The local incidence of this possibly devastating injury is unknown but account for $11.1 \%$ of all ocular injury in Benin city ${ }^{3}$ Nigeria and 7-9.9\% in other parts of the world. ${ }^{1,4}$

Chemical trauma to the eye may vary in severity 
from mild irritation to complete destruction of the ocular surface epithelium, cornea opacification, loss in vision and rarely loss of the eye. ${ }^{1}$ Alkali injuries are usually more severe than acid injuries the latter tending to remain confined to the ocular surface and producing superficial damage. ${ }^{2}$ It is also known that alkali injuries tend to be more common since they are extensively used in industries and in various households as cleansing agent. ${ }^{5}$ Acute ocular chemical injuries require urgent recognition and management. Copious irrigation of the eye done immediately at the scene is the most important factor in the management of ocular chemical burns. ${ }^{2,6}$ This study was conducted to review cases of ocular chemical injuries that presented at our hospital over an 8-year period in order to determine the aetiology and pattern of presentation as well as review challenges in their management. The findings will help to suggest preventive measures as well as suggest ways of improving management.

\section{Materials and Method}

This is a retrospective study of all consecutive patients who presented to the eye clinic as well as the plastic and reconstructive unit of our between March 1998 and April 2006 spanning over eight years. The case files of all affected patients were retrieved from the record department and the relevant data such as sex, age, time of presentation after the injury, cause of injury, pattern of management duration of stay in the hospital and visual outcome were extracted. Staging of the injury was by Roper Hall classification ${ }^{7}$ as stated below:

Stage 1: Cornea epithelial loss with no limbal ischemia. Stage 2: Cornea stromal haze but iris visible, limbal ischemia less than one third. Stage 3: Widespread stromal haze iris details obscured with limbal ischemia between one third and half. Stage 4: Opaque cornea, no view of iris detail and limbal ischemia more than half. The data was analyzed. Clinical photographs were taken after obtaining the permission of the involved patient. Patients were usually jointly managed by the Ophthalmologist and plastic surgeon. The duration of follow up varied from one month to five years.

\section{Results}

The number of patients seen during the period under review was twenty three involving thirty three eyes. There were nineteen males and four females with ratio 4.7:1. Their age and vocation is as shown in table 1 .

Injury was accidental in $73.9 \%$ and as a result of assault in $26.1 \%$ Figure 1 . The motive behind the assault cases includes robbery in three cases and interpersonal clashes in the other three cases. The injurious substances were as shown in table 2 .
The interval between the injury and presentation for treatment varied, $25 \%$ of the patients presented within 6 hours of injury and 50\% within 24 hours. About $25 \%$ of the patients had the affected eyes irrigated with water before presenting at the teaching hospital. Duration of admission varied from 4 to 120 days with an average of 41.33 days._Both eyes were affected in 10 patients giving $43.4 \%$ bilaterality. The cases of assault were all bilateral.

Ocular complications seen are outlined in table 3 while the staging of the chemical burn and consequent visual outcome is shown in table 4.

Table 1: Age and vocation of 23 patients with chemical injury

\begin{tabular}{ll}
\hline Variable & No. \\
\hline Age (years) & 3 \\
$0-15$ & 10 \\
$16-30$ & 8 \\
$31-45$ & 2 \\
$46-60$ & \\
Vocation & 8 \\
Student & 6 \\
Artisan (welder, battery charger) & 3 \\
Trader & 2 \\
Factory worker & 1 \\
Lecturer & 3 \\
Civil servant & \\
\hline
\end{tabular}

Figure 1: Pattern of chemical eye injury and bilaterality in 23 patients

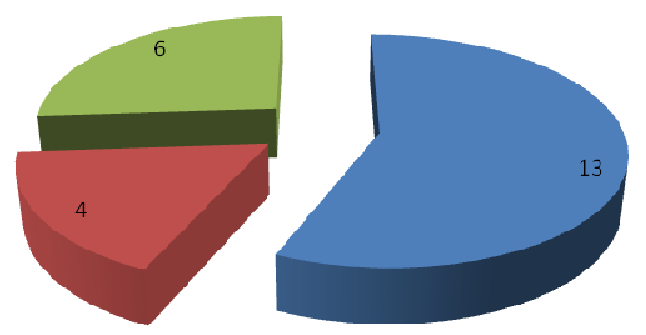

\# Accidental, unilateral $\quad$ Accidental, bilateral $\quad$ Assault, bilateral

Table 2: Nature of injurious agent in 23 patients with chemical eye injuries

\begin{tabular}{ll}
\hline Injuring agent & No. \\
\hline Acid (sulphuric acid, hydrochloric acid) & 11 \\
Calcium hydroxide & 3 \\
Insecticide aerosol & 2 \\
Sodium hydroxide & 1 \\
Unknown & 5 \\
\hline Total & 23 \\
\hline
\end{tabular}


Table 3: Visual acuity of 33 eyes in 23 patients with chemical eye injuries

\begin{tabular}{lll}
\hline Visual acuity & At presentation $(\%)$ & At final follow up $(\%)$ \\
\hline $6 / 6-6 / 18$ & $16(48.5)$ & $20(60.6)$ \\
$6 / 24-3 / 60$ & $7(21.2)$ & $2(6.1)$ \\
$<3 / 60-$ PL & $8(24.2)$ & $3(9.1)$ \\
NPL & $2(6.1)$ & $8(24.2)$ \\
\hline Total & $33(100)$ & $33(100)$ \\
\hline
\end{tabular}

PL: perception of light; NPL: no perception of light

Table 4: Ocular complications of chemical eye injuries in 33 eyes

\begin{tabular}{ll}
\hline Ocular complication & No. $(\%)$ \\
$\mathrm{n}=33$
\end{tabular}

Table 4: Degree of ocular burns and final visual acuity of 33 eyes in 23 patients with chemical eye injury

\begin{tabular}{lllllll}
\hline Grade & $\begin{array}{l}\text { VA at } \\
\text { admission }\end{array}$ & \multicolumn{5}{l}{$\begin{array}{l}\text { VA at } \\
\text { discharge }\end{array}$} \\
\hline & $6 / 6-6 / 18$ & $6 / 24-3 / 60$ & $<3 / 60-$ NPL & $6 / 6-6 / 18$ & $6 / 24-3 / 60$ & $<3 / 60-$ NPL \\
1 & 16 & - & - & 16 & - & - \\
2 & - & 4 & - & 3 & 1 & - \\
3 & - & 2 & 3 & 1 & - & 8 \\
4 & - & 1 & 7 & - & 2 & 11 \\
\hline \multicolumn{2}{l}{ Total } & 16 & 7 & 10 & 20 &
\end{tabular}

\section{Discussion}

The prevalence of chemical eye injury was $2.2 \%$ of the total no of 1065 patients who had eye injury during the period under study. This hospital incidence is low when compared to $11.1 \%$ found in Benin City, Nigeria and general value of $7-9.9 \%$ in the literatures for all hospital incidences. ${ }^{3,4}$ This may be a reflection of the fact that the state has few industries in general and industries using chemicals in particular. However being a hospital based study might have introduced some bias.

Males were predominantly affected (82.6\%) similar to that found in the study in Benin $91.7 \%$ and by Morgan in London $84.5 \%{ }^{5}$ just as ocular trauma in general is known to be commoner in males. ${ }^{8,9}$ This is probably due to the fact that males are more involved in works such as mechanics, automobile battery charging and welding. However unlike the studies in Benin City, Nigeria, where $83.3 \%$, Davis ${ }^{10}$ and Beare $^{11}$ in London who had $84 \%$ and $80 \%$ of the ocular burns due to assault respectively only $26.1 \%$ of our cases resulted from assault, the remaining being primarily accidental and work related. The predominantly accidental nature has a bearing on the severity of the initial injury and subsequently the better visual outcome in this study. It is known generally that cases due to assault tend to be more severe in terms of ocular tissue damage and visual loss at presentation as shown in studies carried out by Ukponmwan, ${ }^{3}$ this was also the finding in this study. All our cases resulting from assault were bilateral and all the patients became blind. We observed that the 13 out of 17 accidental cases occurred at workplace and none of the victims had protective eye glasses on at the time of the accident. This is a reflection of the poor safety awareness and practices among workers. ${ }^{12}$

Although chemical eye injuries are infrequent and relatively trivial, some are potentially blinding. ${ }^{4,9}$ In this study $33.3 \%$ had blindness in the affected eyes $(\mathrm{VA}<3 / 60)$ as a result of the ocular burns sustained. The major risk factor for blindness was the grade of 
ocular injury at presentation. Bilateral involvement occurred in $43.4 \%$ of our cases slightly higher than the upper limit in the literatures of $23-42 \%$ of cases 5 . This means that about half of persons with chemical eye injury will have both eyes involved with the resultant possibility of suddenly becoming blind. The need for good sight among the age group 16-45 years commonly involved cannot be over emphasized.

In patients with assault the chemical component of injurious agent was not known because remnants are rarely left behind. While in accidental cases chemical nature was as available by circumstantial clinical history except in patients where the actual chemical was labeled. Acid was the commonest among the identified group and usually in automobile battery charger cum mechanic while at work.

$\mathrm{PH}$ of conjunctiva could not be done due to late presentation and lack of litmus paper. Availability of common litmus paper will help in assessing the PH of the fornix as well as determine adequate irrigation. Intraocular pressure check which is a necessity in some of the patients was difficult with contact tonometry. Lack of Markey Merg or pneumotonometer made it impossible to check the intraocular pressure.

Immediate Copious and prolonged irrigation with water which is the most important emergency treatment of chemical ocular burns was not done in the majority of the patients due to lack of awareness by the people and this could have worsen the final visual outcome.

Standard alkali burn treatment protocol which includes intensive topical steroids, ascorbate citrate and antibiotics ${ }^{13}$ could not be strictly followed in suspected alkaline burns due to unavailability of topical ascorbate and citrate. In a study by Brodovsky ${ }^{13}$ it was shown that this intensive therapy led to more rapid cornea reepitheliazation in grade 3 injuries with better visual outcome though there was no significant difference in the grade 4 injury patient and Davis also found that prolonged steroid use in conjunction with topical and oral vitamin $\mathrm{C}$ does not cause cornea melting. ${ }^{10}$ Topical steroid had to be cautiously used for 10 days to reduce the risk of corneoscleral melting. One patient had topical citrate and ascorbate commenced two weeks after the chemical injury due to delay in arrival of the drugs and did not yield the desired result. Recently it being shown that topical ascorbate can be locally produced by adding Potassium ascorbate $10 \%$ into viscoelastic or aqueous solution to make $1 \%$ topical ascorbate ${ }^{10,14}$ this will be tried in subsequent patients. In our series oral Vitamin C $1 \mathrm{gm}$ daily and tetracycline $2 \mathrm{~g}$ daily was used.

Debridment, puncta occlusion and tarsorraphy were the only surgical intervention available. Limbal stem cell auto or allograft, penetrating keratoplasty which could facilitate development of phenotypically correct cornea epithelium ${ }^{16,17}$ could not be done. Tissue adhesive Isobutyl cyanoacrylate was not also available. These are necessary procedures if meaningful help will be rendered to patients with severe burns. Most of the facial wounds were dressed openly with the use of silver sulphadiazine and honey. Two of our patients had wound excision with split thickness skin graft (STSG) of their facial wound while one patient had release of ectropion of the upper eyelid with STSG. A patient offered evisceration had shallow orbit resulting from the burns and could not retain an artificial eye.

Rehabilitation of the bilaterally blind was difficult since there were no blind schools catering for the adult blind. The chemical injured patients with the accompanying facial deformity faces a lot of psychological and emotional trauma whose need cannot be adequately met in the main stream of presently busy eye care. Behavioral scientists and psychologist, workers in rehabilitative centers should be involved to enable the victims come out of the possible depression and live a meaningful life thereafter.

Occupational health issues such as prevention of injury at work and laws to ensure adequate care of victims by employer as well as proper compensation should be enforced. Effort should be geared at educating and promoting use of safety eyewear by workers. Easy access to acid by anyone needs regulation. Eye care providers and our health institutions need to be better prepared to care for the chemically eye injured patients.

\section{References}

1. Pfister RR. Chemical Injuries to the eye. Ophthalmology 1983; 90:1246- 1253

2. Burns FR, Paterson CA. Prompt irrigation of chemical injuries may avert severe damage. Occup Hlth 1985; 58: 33-36

3. Ukponmwan CU. Chemical injuries to the eye in Benin City, Nigeria. West Afr J Med 2000; 19: 71-76

4. Vermon SA. Analysis of all new cases seen in a busy regional center ophthalmic casualty department during a 24 -week period. J R Soc Med J 1989; 76: 279-282

5. Morgan SJ. Chemical Injuries of the eye: causes and management. Br J Ophthalmol 1987; 71: 854-857

6. Lusk PG. Chemical eye injuries at workplace: prevention and management. AAOHN J 1999; 47: 80-87

7. Sainnai JA, Sharma A. Ocular chemical burns: clinical and demographic profile. Burns 1993; 19:67-69

8. Khatry SK. The epidemiology of ocular trauma in rural Nepal. Br J Ophthalmol 2004; 88: 456460

9. Nirmalan PK. Ocular trauma in rural south Indian population: the Aravind comprehensive eye survey. Ophthalmology 2004; 111: 1778-1781

10. Davis AR, Ali QH, Aclimandos WA, Hunter PA. Topical steroid use in the treatment of ocular alkali burns. Br J Ophthalmol 1997; 81: 732-734

11. Beare J. Eye injuries from assault from chemicals. Br J Ophthalmol 1990; 74:514-518 
12. Okojie OH, Isah EC. Assessment of occupational hazard among beautician in Benin City. Niger $\mathbf{J}$ Clin Pract 2001; 4: 25-27

13. Brodovsky SC, McCarty CA, Snibson G, et al. Management of alkali burns: an 11-year retrospective review. Ophthalmology 2000; 107: 1829-1835

14. Dutta LC, Dutta K. Ocular chemical burns. In: Modern ophthalmology. Jaypee Press, 2005:231232
15. Rein M, Bahrke C, Kukelkohn R, Kuwert T. Investigation of enzyme activities in severe burns of the anterior segment. Graeffes Arch Clin Exp Ophthalmol 1993; 231: 308-310

16. Morgan SJ, Murray A. Limbal autotranplantation in acute and chronic phases of severe chemical injuries. Eye 1996; 10: 349-354

17. Wagoner MD. Chemical injuries to the eye: current concepts in pathophysiology and therapy. Surv Ophthalmol 1997; 41: 275-313 